dr inz. Marian Kaluba

mgr inz. Damian Goliwas

Instytut Pojazdów Szynowych ,, TABOR”

\title{
Modułowy system sterowania hamulcami pojazdów trakcyjnych
}

\begin{abstract}
W artykule opisano podziat strukturalny i funkcjonalny uktadu pneumatycznego pojazdów szynowych spotykanych we wspótczesnym transporcie kolejowym.

Integracja wyodrębnionych uktadów funkcjonalnych wymaga użycia urzqdzeń z różnych grup strukturalnych. Podziat strukturalny $i$ funkcjonalny układów oraz integracja $w$ niezależne moduty umożliwit elastyczne projektowanie różnorodnych konfiguracji układów pneumatycznych (w tym hamulcowego) dedykowanych do poszczególnych pojazdów.

Dodatkowo przedstawiono moduly sterowania elektronicznego i pneumatycznego, które opracowano w Instytucie Pojazdów Szynowych „,TABOR” w Poznaniu, będace elementami sktadowymi projektowanych przez Instytut uktadów hamulcowych i pomocniczych układów pneumatycznych.
\end{abstract}

\section{Wprowadzenie}

Współczesne systemy transportu i komunikacji kolejowej wymagają wielu różnych pojazdów trakcyjnych. Sa to autobusy szynowe, zespoły trakcyjne komunikacji miejskiej (metro, szybka kolej miejska), zespoły trakcyjne bliskiej komunikacji wokół aglomeracji miejskich, zespoły trakcyjne komunikacji między miastowej, zespoły trakcyjne dużych prędkości, lokomotywy różnych typów (od manewrowych, towarowych, osobowych do liniowych na duże prędkości). Pojazdy te mogą być o napędzie spalinowym lub elektrycznym.

Każdy $\mathrm{z}$ tych pojazdów wymaga nieco innego wyposażenia hamulcowego i innego wyposażenia $\mathrm{w}$ pomocnicze układy pneumatyczne. Prowadzi to do konieczności realizowania wielu projektów i wdrożeń różnych układów hamulcowych i pneumatycznych. Koszt realizacji tak wielu projektów byłby duży a czas realizacji niezbędny do ich wdrożenia bardzo długi. Od kilkudziesięciu lat firmy produkujące układy hamulcowe, aby sprostać temu wyzwaniu, opracowuja powtarzalne moduły pneumatyczne, które następnie integruja w kompletne układy hamulcowe lub pneumatyczne.

\section{Przesłanki budowy modułowej}

Budowę modułową sterujących układów hamulcowych i pneumatycznych wymuszają następujące podstawowe czynniki:

- bardzo zróżnicowane wymagania przewoźników,

- zapotrzebowanie na dużą różnorodność pojazdów trakcyjnych,

- zróżnicowane strategie wdrażania do produkcji pojazdów nowych i modernizowanych,

- poszukiwanie kompromisu przez integratorów pojazdów pomiędzy kosztami projektu i zakresem realizowanych funkcji układów pneumatycznych,

- minimalizowanie kosztów projektowania i badań nowych układów oraz pojazdów (poprawa efektywności opracowywania nowych projektów),

- skracanie czasu niezbędnego do wdrożenia nowych układów hamulcowych i pojazdów. 


\section{Podział strukturalny i funkcjonalny układu sterowania hamulcami i pneumatyką}

Elementy układów sterowania hamulcami i pneumatyką można podzielić na trzy grupy strukturalne:

- Układy elektronicznego sterowania hamulcami EBC (elektronic bracke control)

- Pneumatyczne układy sterowania hamulcami PBC (pneumatic bracke control) oraz pneumatyczne układy pomocnicze i zasilające PAC (pnematic auxiliary control)

- Pulpitowe urządzenia sterujące

Podział funkcjonalny układów sterowania hamulcami i układami pneumatycznymi dla pojazdów trakcyjnych jest następujący:

- układ hamulca zespolonego pociagu (funkcja zaworu maszynisty dla lokomotyw lub dla zespołów trakcyjnych)

- układ hamulca dodatkowego (dla lokomotyw)

- lokomotywowy układ sterowania hamulcem elektropneumatycznym pociagu zestawionego z wagonów (typu automatycznego EP-A) i mostkowania uruchomionego hamulca bezpieczeństwa przez pasażera

- układ hamulca elektropneumatycznego typu bezpośredniego EP-B (dla zespołów trakcyjnych), ze sterowaniem binarnym lub ze sterowaniem sygnałem o zmiennej szerokości pulsu

- układ realizujący ciągłą i płynną zmianę siły hamowania pojazdu w funkcji przewożonego ładunku z możliwością korekcji zapewniającej stałe opóźnienie pojazdu wyposażonego w hamulec klockowy

- układ realizujący skokową zmianę siły hamowania w funkcji przewożonego ładunku (jako tańsza alternatywa płynnej zmiany siły hamowania dla pojazdów o względnie niewielkim przewożonym ładunku)

- układ hamulca szynowego

- układ współpracy hamulca elekrodynamicznego (ED) z hamulcem pneumatycznym (tzw. Blending)

- układ samoczynnego hamowania pociagu (SHP)

- układ zdalnego hamowania pociągów na sygnał radiowy (Radiostop)

- układ czuwaka aktywnego

- układ hamulca bezpieczeństwa pasażerów

- układ mostkowania hamulca bezpieczeństwa pasażerów dla zespołów trakcyjnych

- układ hamulca postojowego

- układ syren i generowania sygnałów alarmowych

- układ podnoszenia odbieraków

- układ zasilania piasecznic
- układ zasilania smarowania obrzeży

- układ blokady szaf wysokiego napięcia

- układ rozrządu sprężonego powietrza dla aparatów elektrycznych

- układ zasilania usprężynowania pneumatycznego pojazdu

- układ diagnostyki pomiarowej parametrów hamulca i pomocniczych obwodów pneumatycznych

- układ wspierający realizację prób stacjonarnych wykonywanych przez maszynistę, obejmujący automatyczne przeprowadzenie próby stacjonarnej hamulca

\section{Moduły elektronicznego sterowania}

IPS "Tabor" opracował i wdrożył do produkcji rodzinę modułów elektronicznych - sterowników mikroprocesorowych. Zrealizowano ideę w której kilka modułów (sterowników) mocowanych na listwie montażowej połączonych siecią między sobą, tworzy kompletny mikroprocesorowy układ sterowania cała pneumatyką danego pojazdu. Wydzielone sterowniki w takim układzie realizują centralne sterowanie hamulcami, inne sterują wartościami regulowanych ciśnień a inne spełniają funkcje dla poszczególnych układów funkcjonalnych oraz jeszcze inne funkcję wejść i wyjść sprzętowych i programowych poprzez sieć informatyczną (np. CAN). IPS "Tabor" przyjął zasadę, że moduły te stanowią część elektryczną całkowicie zintegrowaną $\mathrm{z}$ tablicą pneumatyczną. Zaletą takiego rozwiązania jest bardzo istotne ograniczenie okablowania na pojeździe (nie ma osobnej skrzyni lub kasety $z$ układami elektronicznymi, jak to realizują inne firmy, i co za tym idzie brak jest połączeń pomiędzy częścią elektryczną a tablicą pneumatyczną), przez co upraszcza się i istotnie przyspiesza montaż układu na pojeździe i zapewnia się jego bezproblemowe uruchomienie na pojeździe. Dodatkową zaletą jest również to, że kompletny układ pneumatycznoelektryczny zajmuje bardzo mało miejsca.

Osobnymi modułami mikroprocesorowymi, nie integrowanymi na tablicach pneumatycznych, sa:

- sterownik układu przeciw poślizgowego przygotowany przez IPS dla pojazdów czteroosiowych lub sześcioosiowych współpracujący z czujnikami prędkości firmy Lenord,

- rodzina manipulatorów pulpitowych opracowana zgodnie z wytycznymi karty UIC 612,

- mikroprocesorowe, analogowe czujniki obciążenia pojazdu ładunkiem dla układu $\mathrm{z}$ automatyczną i płynną zmianą skuteczności hamowania (zmiany ciśnienia w cylindrach) w funkcji ładunku, które umożliwiają na pojeździe bardzo łatwą regulację układu 
- poprzez ich justowanie dla stanu w połowie ładownego, poprzez przycisk justujący. Czujniki te znajduja zastosowanie dla pojazdów z płynną zmianą siły hamowania $\mathrm{w}$ funkcji przewożonego ładunku a nie posiadających usprężynowania pneumatycznego i nie mających możliwości zabudowy pneumatycznych zaworów ważących. To rozwiązanie znalazło powszechne zastosowanie $\mathrm{w}$ modernizowanych $\mathrm{w}$ ostatnich dwu latach zespołach trakcyjnych EN57.

Opracowane moduły połączone w system sterowania, spełniają wymagania $\mathrm{w}$ zakresie kolejowych napięć zasilania (PN/EN ) i kompatybilności elektromagnetycznej (PN/EN ) co zostało potwierdzone badaniami przez akredytowane laboratoria.

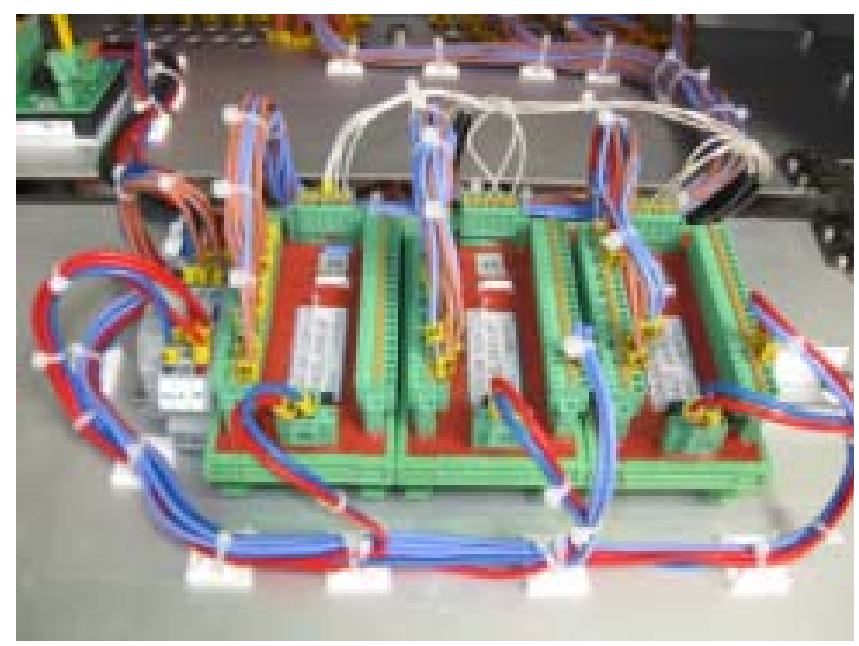

Rys. 1. Rodzina sterowników mikroprocesorowych

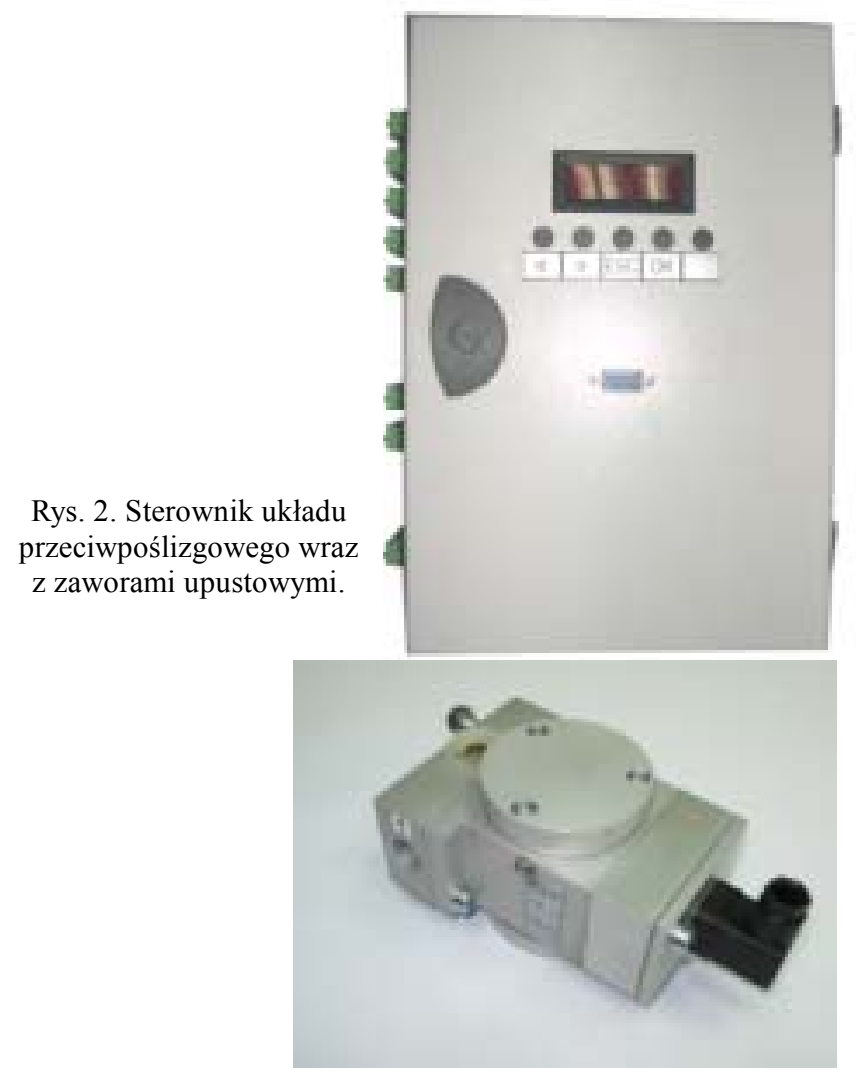

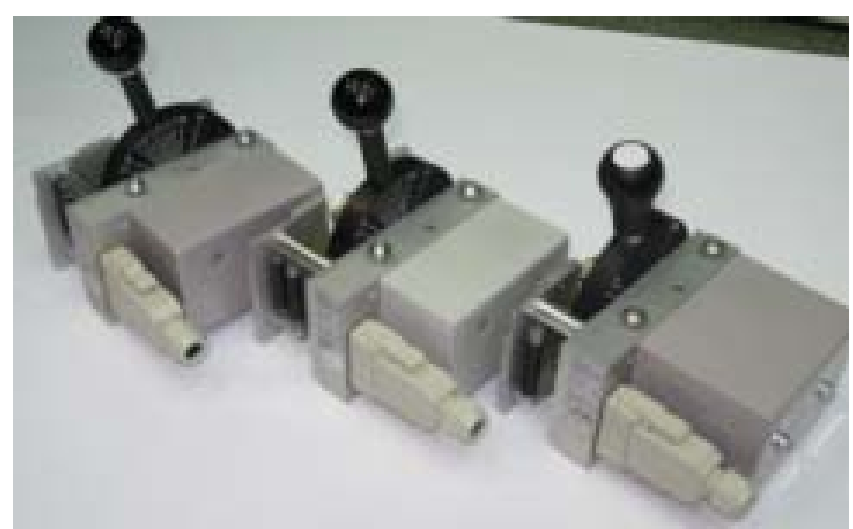

Rys.3. Rodzina manipulatorów pulpitowych.

$\mathrm{Na}$ rysunku 1 pokazano rodzinę modułów elektronicznych - sterowników mikroprocesorowych. Na rysunku 2 sterownik układu przeciwpoślizgowego $\mathrm{z}$ zaworem upustowym. Rodzina manipulatorów obejmuje manipulatory napędu i hamowania, manipulatory hamulca zespolonego, manipulatory hamulca dodatkowego oraz manipulatory do sterowania jedynie napędem pojazdu trakcyjnego. Pokazano je na rysunku 3. Ze względów bezpieczeństwa zgodnie $\mathrm{z}$ zasada redundancji, funkcje zadawane przez maszynistę każdym z manipulatorów, są realizowane na drodze elektronicznej $\mathrm{z}$ wykorzystaniem enkoderów (możliwość płynnej regulacji siły hamowania) oraz równocześnie na drodze sprzętowej, sygnałami binarnymi i to niezależnie od tego czy realizowane jest sterowanie hamulcem elektropneumatycznym czy pneumatycznym zespolonym. Funkcja hamo-wania nagłego ze względu zapewnienia najwyższego stopnia bezpieczeństwa jest realizowana przez manipulator trzema niezależnymi torami (potrójna redundancja): przez enkoder i dwoma układami sprzętowymi przez otwarcie łączników realizujących zanik sygnałów binarnych, co zapewnia również samoczynne i pewne wdrażanie hamowania nagłego $\mathrm{w}$ przypadku awarii zasilania elektrycznego. Hamowanie nagłe jest realizowane sprzętowo w wypadku nawet krótkotrwałego zaniku napięcia zasilania. Hamowanie nagłe realizowane zaworami na tablicach pneumatycznych (otwieranie przewodu głównego dużym przekrojem do atmosfery) IPS "Tabor" realizuje zawsze trzema niezależnymi drogami pneumatycznymi (również potrójna redundancja). Dodatkowo w systemie sterowania hamulcem zespołów trakcyjnych, układ sterowania hamulcami elektrodynamicznym i elektro-pneumatycznym na tablicy jest w sposób ciągly diagnozowany i w przypadku nawet chwilowej awarii (zaniku napięcia lub sygnałów sterujących), układ automatycznie przechodzi ze sterowania MED na EP oraz w przypadku awarii hamulca EP przechodzi również samoczynnie bez zwłoki i bez konieczności ingerencji ze strony maszynisty na sterowanie hamulcem zespolonym pneumatycznym. Dzięki takim 
oryginalnym rozwiązaniom, zapewniającym wysoki stopień bezpieczeństwa, IPS "Tabor" stosuje w układach na pulpitach zespołów trakcyjnych tylko jeden manipulator hamowania hamulcem zespolonym i elektropneumatycznym w odróżnieniu od innych firm hamulcowych. Zaletami takiego rozwiązania jest dodatkowo prosta obsługa hamulca przez maszynistę co zapewnia (szczególnie w sytuacjach zdarzeń nadzwyczajnych, awaryjnych lub krytycznych), właściwe odruchy maszynisty realizowane przez niego bez żadnej zwłoki czasowej. Wszystkie te czynniki powodują, że układ taki $\mathrm{w}$ porównaniu $\mathrm{z}$ układami $\mathrm{z}$ wieloma manipulatorami oferowanymi przez inne firmy jest prostszy w obsłudze i zabudowie na pulpicie przy zachowaniu bardzo wysokiego stopnia bezpieczeństwa.

Dla układów lokomotywowych stosowane są dwa manipulatory: hamulca zespolonego i dodatkowego na każdym stanowisku maszynisty. Przygotowane przez IPS Tabor manipulatory jazdy i hamowania lub manipulatory jazdy, umożliwiają zaprojektowanie pulpitu z manipulatorami o podobnym wyglądzie i takim samym sposobem mocowania. Przyjęty sposób mocowania zapewnia bardzo łatwy ich montaż, co umożliwia ewentualną bardzo szybką wymianę manipulatora w pulpicie (wymaganą kartą UIC 612).

Dla każdej z wyżej wymienionej funkcji opracowano standardowe, sprawdzone w eksploatacji bloki oprogramowania. Na przykład:

1. dla zaworu maszynisty lokomotyw zgodnie $z$ wymaganiami karty UIC 541-03 (modernizowane lokomotywy ET22, EU07, 6Dg, 6Dk, SM48, ST45, ST46)

2. dla zaworu maszynisty zespołów trakcyjnych $\mathrm{z}$ uproszczonymi funkcji $\mathrm{w}$ porównaniu $\mathrm{z}$ zaworami maszynisty dla lokomotyw (zespoły trakcyjne EN57, EN71, EN72 i EN97 dla WKD),

3. hamulca dodatkowego lokomotyw (modernizowane lokomotywy ET22, EU07, 6Dg, 6Dk, SM48, ST45, ST46),

4. dla dodatkowego impulsowego manipulatora jazdy i hamowania do realizowania jazd manewrowych realizowanych przy uchylonym oknie bocznym kabiny maszynisty (EU07),

5. hamulca EP typu bezpośredniego dla zespołów trakcyjnych ze sterowaniem binarnym wzdłuż składu pociagu (EN57, EN71, EN72) lub ze sterowaniem sygnałem o zmiennej szerokości pulsu (EN97),

6. dla układu realizującego automatyczną i płynną zmianę siły hamowania pojazdu $\mathrm{w}$ funkcji ładunku wraz z korektą zapewniająca stałe opóźnienie zespołu trakcyjnego wyposażonego w hamulec klockowy (EN57, EN71, EN72 i EN97),
1. dla układu współpracy hamulca ED i hamulca pneumatycznego (we wszystkich nowych i modernizowanych lokomotywach i zespołach trakcyjnych $\mathrm{z}$ hamulcem ED z możliwością płynnej zmiany siły hamowania ED w funkcji ładunku),

2. dla współpracy układów przeciwpoślizgowych hamulca elektrodynamicznego (ED) i hamulca pneumatycznego,

3. typowych zautomatyzowanych procedur diagnostycznych dla wyżej przedstawionych funkcji.

Dla układów pomocniczych IPS każdorazowo opracowuje algorytmy działania według życzeń zamawiającego.

\section{Moduły sterowania pneumatycznego}

Jednym z podstawowych modułów pneumatycznych jest zawór rozrządczy. IPS "Tabor" stosuje w opracowanych układach hamulca pojazdów trakcyjnych, homologowane zawory rozrządcze spełniające wymagania UIC i TSI produkcji firm europejskich (Faiveley SW, Wabtec MH i Fablok BF). Kolejnymi istotnymi modułami sterowania pneumatycznego są przekładniki ciśnienia. W IPS "Tabor" opracowano rodzinę przekładników ciśnienia do napełniania cylindrów hamulcowych i przewodu głównego. Przekładniki do napełniania przewodu głównego znajdują zastosowanie w układach zaworu maszynisty. Dla lokomotyw jest to przekładnik posiadający możliwości realizowania bardzo dużych natężeń przepływu sprężonego powietrza, który współdziałając z sub-modułem dławiącym realizuje zmienne i różne wymagane przepisami zdolności napełniania $\mathrm{w}$ zależności od pozycji manipulatora hamulca ( inne w pozycji gotowości do jazdy, inne w pozycji hamowania $\mathrm{i}$ odhamowania oraz inne $\mathrm{w}$ pozycji napełniania przewodu głównego wysokim ciśnieniem). Dla zespołów trakcyjnych, w których funkcja zaworu maszynisty jest uproszczona (brak napełniania wysokim ciśnieniem) i nie występuje zapotrzebowanie na zdolność napełnianie przewodu głównego o dużej pojemności (relatywnie krótkie pociągi z przewodem głównym 1"), opracowano mniejszy przekładnik o mniejszych przekrojach przepływu. Przekładniki te przedstawiono na rys. 4.

Przykładowe przekładniki ciśnienia $\mathrm{z}$ rodziny przekładników służących do napełniania cylindrów pokazano na Rys.5. Do tej grupy należą przekładniki o stałym przełożeniu pomiędzy ciśnieniem sterującym i ciśnieniem w cylindrze (jedno i dwustopniowe $\mathrm{z}$ możliwością realizowania współpracy $\mathrm{z}$ hamulcem ED na drodze pneumatycznej) oraz przekładniki ciśnienia o płynnie zmieniającym się przełożeniu (w funkcji przewożonego ładunku) pomiędzy ciśnieniem sterującym i ciśnieniem w cylindrze. Każdy z tych przekładników o płynnie zmieniającym się ciśnieniu 
cylindrowym w funkcji ładunku może być jednostopniowy lub dwustopniowy w celu realizowania nastawienia „osobowy” lub ,pospieszny”.

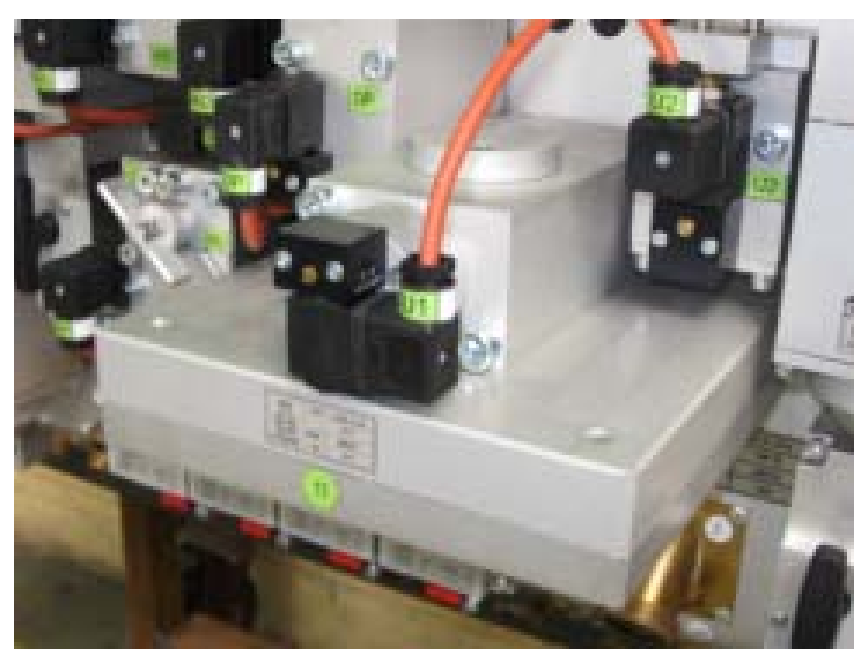

Rys.4. Przekładniki ciśnienia do napełniania przewodu głównego (dla lokomotyw i dla elektrycznych zespołów trakcyjnych)

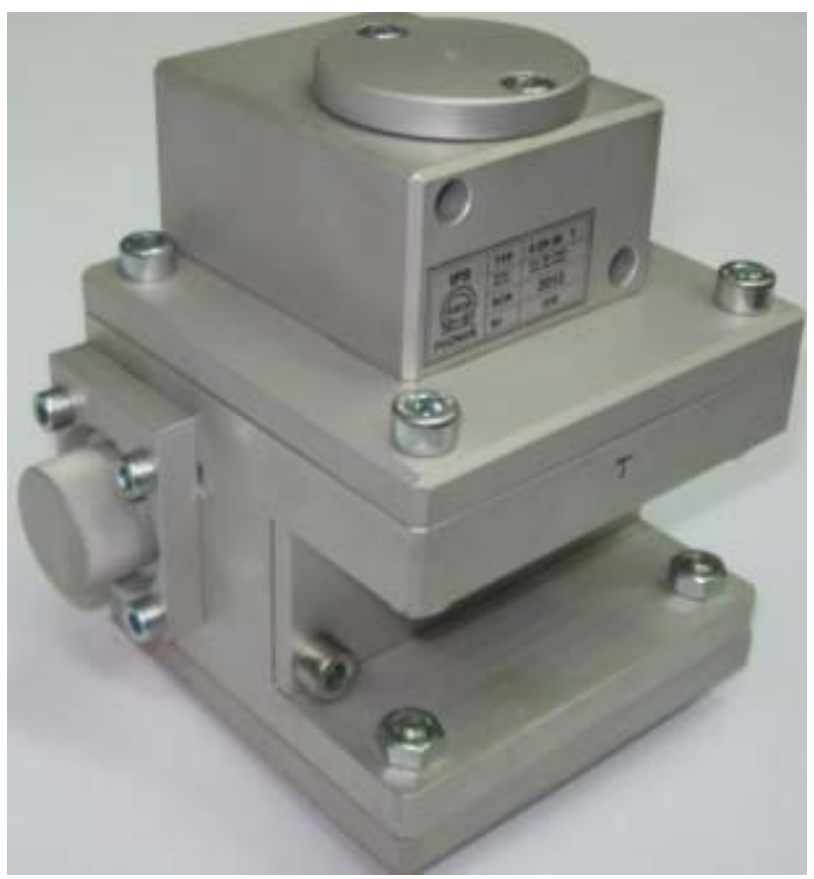

Rys.5. Przekładniki ciśnienia do napełniania cylindrów hamulcowych o stałym i zmiennym przełożeniu realizujące płynną zmianę ciśnienia cylindrowego w funkcji ładunku

IPS "Tabor" przyjął zasadę, że dla układu hamulca pneumatycznego (a nie tylko elektropneumatycznego) we wszelkich zespołach trakcyjnych poczynając od miejskich (WKD Warszawa), poprzez podmiejskie (EN57 modernizowane od 2010 roku) aż do zespołów na duże prędkości będzie stosował w układach hamulca pneumatycznego pojazdu płynną i automatyczną zmianą ciśnienia $\mathrm{w}$ cylindrach $\mathrm{w}$ funkcji ładunku i w funkcji stopnia hamowania, a nie jedynie sterowanego wielkością ładunku ogranicznika maksymalnego ciśnienia $\mathrm{w}$ cylindrach jak to proponuje w swoich niektórych układach (np. EP-
Compakt) firma Knorr-Bremse. Stało się to możliwe w wyniku opracowania przekładnika ciśnienia wg patentu IPS $\mathrm{z}$ automatyczną zmianą ciśnienia w cylindrze $\mathrm{w}$ funkcji ładunku o niewielkiej masie i niewielkich rozmiarach, specjalnie przystosowanego do montażu płytowego na tablicy pneumatycznej.

W zakresie modułów generujących ciśnienia sterujące na sygnał elektryczny (na przykład dla ciśnień sterujących przekładników), opracowano dwa moduły: tak zwane wyspy zaworowe, które w jednym korpusie posiadaja dwa lub cztery zawory elektropneumatyczne sterowane mikroprocesorowo. Wyspy zaworowe przedstawiono na Rys 6. Moduly te moga występować pojedynczo lub w zależności od potrzeb można je łączyć ze sobą w wyspy wielo-zaworowe. Realizują one we współpracy $\mathrm{z}$ regulatorami mikroprocesorowymi wymagane przebiegi ciśnień $\mathrm{W}$ funkcji czasu, dla wszelkich układów w których występuje potrzeba sterowania ciśnieniem sygnałami elektrycznymi. Kolejnymi modułami pneumatycznymi opracowanymi przez IPS są moduły diagnostyczne do kontroli wartości ciśnień.

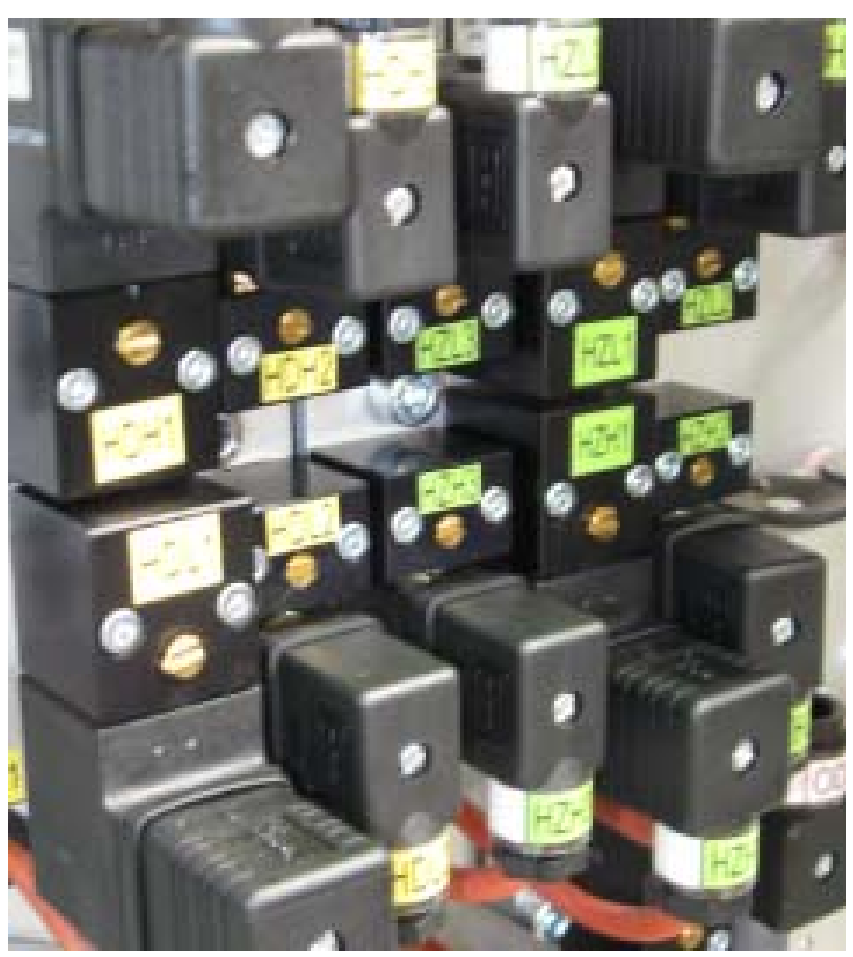

Rys. 6. Wyspy zaworowe do generowania ciśnień sterujących.

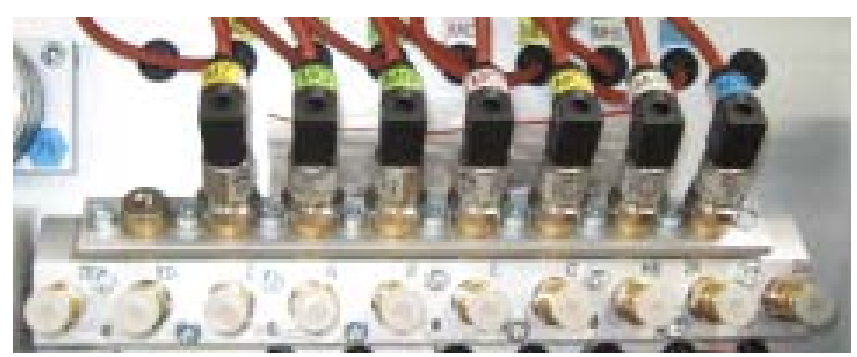

Rys.7. Moduły diagnostyczne 
Moduły diagnostyczne składają się z czujników ciśnienia, wyłączników ciśnienia i króćców pomiarowych realizowanych jako szybko-złączki (Rys.7).

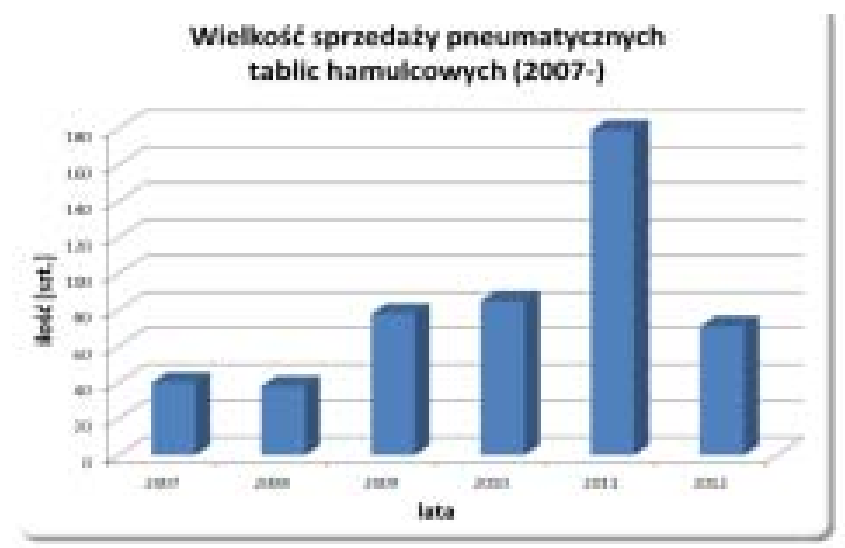

Wykres 1. Wielkość sprzedaży pneumatycznych tablic hamulcowych (stan na II kwartał 2012r.)

Przykładowo, w ostatnim czasie Instytut Pojazdów Szynowych TABOR w Poznaniu opracował i wdrożył zintegrowane systemy hamulcowe oparte na opracowanych modułach dla: zespołów trakcyjnych EN-57, EW-60, EN-71 i EN-72 modernizowanych przez Newag Nowy Sącz i ZNTK Mińsk Mazowiecki dla Przewozów Regionalnych, EN-97 nowy pojazd wyprodukowanego przez PESA Bydgoszcz dla
Struktura produlccji pneumatycznych tablic hamulcowych (2007-)

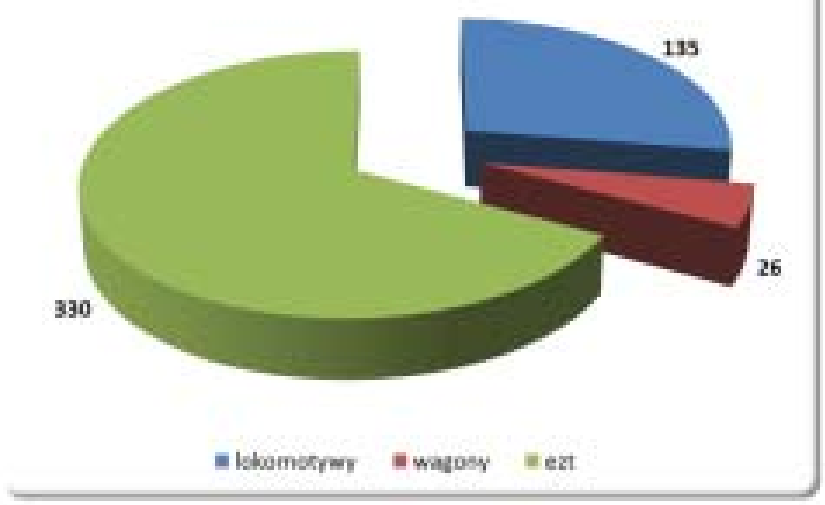

Wykres 2. Struktura produkcji pneumatycznych tablic hamulcowych (stan na II kwartał 2012r.)

Warszawskiej Kolei Dojazdowej, lokomotyw ET-22, SM-42, ST-44, ST-45, ST-46 dla PKP Cargo i innych prywatnych operatorów.

Na wykresie 2 pokazano strukturę dostaw do Klientów pneumatycznych tablic hamulcowych produkcji Instytutu Pojazdów Szynowych TABOR w Poznaniu. 